\title{
PATOGENISITAS BEBERAPA BAKTERI Vibrio YANG DIISOLASI DARI SEDIMEN TAMBAK TERHADAP UDANG WINDU, Penaeus monodon
}

\author{
Muliani*), Muharijadi Atmomarsono*), dan Nurhidayah*
}

\begin{abstract}
ABSTRAK
Penelitian bertujuan untuk mengetahui tingkat patogenisitas beberapa bakteri Vibrio yang diisolasi dari sedimen tambak terhadap udang windu, Penaeus monodon. Penelitian dilakukan di Laboratorium Basah Balai Penelitian Perikanan Pantai yang meliputi beberapa tahapan kerja yaitu: (1) Isolasi dan identifikasi bakteri Vibrio dari sedimen tambak, (2) Perbanyakan bakteri vibrio hasil identifikasi menggunakan nutrient broth, (3) Infeksi buatan dengan bakteri $V$. alginolyticus, $V$. costicola, V. harveyi, atau V. mimicus dengan kepadatan $10^{2}, 10^{4}$, dan $10^{6} \mathrm{cfu} / \mathrm{mL}$ ke dalam wadah pemeliharaan udang windu, dan (4). Pengamatan perkembangan populasi bakteri Vibrio dan mortalitas udang windu. Rancangan acak lengkap (RAL) dengan pola faktorial diaplikasikan dalam pengujian empat jenis Vibrio dan tiga kepadatan berbeda, masing-masing dengan tiga ulangan. Analisis statistik menunjukkan bahwa pada perendaman 24 jam $\mathrm{V}$. harveyi dengan konsentrasi $10^{6} \mathrm{cfu} / \mathrm{mL}$ menyebabkan kematian paling banyak $(P<0,05)$ dibandingkan perlakuan lainnya. Setelah perendaman 96 jam, kematian udang akibat perlakuan $V$. harveyi $10^{4} \mathrm{cfu} / \mathrm{mL}$ tidak berbeda nyata $(P>0,05)$ dengan periakuan $V$. harveyi $10^{6} \mathrm{cfu} / \mathrm{mL}$ dan $V$. alginolyticus $10^{6} \mathrm{cfu} / \mathrm{mL}$, namun berbeda nyata $(P<0,05)$ dengan perlakuan yang lainnya. Hal ini menunjukkan bahwa $V$. harveyi lebih patogen daripada $V$. alginolyticus, $V$. costicola, dan $V$. mimicus
\end{abstract}

\section{ABSTRACT: Pathogenicity of vibrios isolated from pond sediments on tiger shrimp,} Penaeus monodon. By: Muliani, Muharijadi Atmomarsono, and Nurhidayah.

This experiment aimed to determini the pathogenecity of vibrios isolated from pond sediments on tiger shrimp, Penaeus monodon. This experiment was conducted in wet laboratory of the Research Institute for Coastal Fisheries including several activities i.e. (1) Isolation and identification of vibrios from pond sediments, (2) Cultivation the identified vibrios in nutrient broth medium, (3) Inoculation of $10^{2}, 10^{4}$, and $10^{6} \mathrm{cfu} / \mathrm{mL}$ of $\mathrm{V}$. alginolyticus, $\mathrm{V}$. costicola, $\mathrm{V}$. harveyi, or $\mathrm{V}$. mimicus separately in the shrimp culture media, and (4) Monitoring the population of inoculated vibrios ( $V$. alginolyticus, V. costicola, V. harveyi, and V. mimicus) and mortality of tiger shrimp completely factorial randomized design was applied. Statistical analysis showed that mortality of the tiger shrimp after $24-h$ exposure with $10^{6} \mathrm{cfu} / \mathrm{mL}$ of $\mathrm{V}$. harveyi was significantly higher $(P<0.05)$ than those of the other treatments. After 96-h exposure, mortality of tiger shrimp in $10^{4} \mathrm{cfu} / \mathrm{mL}$ of $\mathrm{V}$. harveyi was not significantly different $(P>0.05)$ with that of $10^{6} \mathrm{cfu} / \mathrm{mL}$ of $V$. harveyi or $V$. alginolyticus, but they were significantly different $(P<0.05)$ with the other treatments. These results showed that $V$. harveyi is the most pathogenic bacteria among the tested vibrios.

KEYWORDS : Vibrio spp., pond sediment, pathogenicity, tiger shrimp

\section{PENDAHULUAN}

Di antara beberapa permasalahan yang timbul dalam usaha budi daya udang windu adalah adanya serangan penyakit baik di panti benih maupun di tambak. Rukyani (1993) melaporkan bahwa akibat adanya serangan penyakit, hanya sekitar $40 \%$ dari seluruh areal pertambakan di Indonesia yang masih beroperasi, sehingga menimbulkan kerugian yang cukup besar. Selanjutnya dikatakan bahwa sekitar 150 milyar rupiah per tahun hilang dari areal pertambakan di Jawa Timur dan sekurang-kurangnya 300 milyar rupiah telah hilang per tahunnya dari seluruh areal pertambakan di Indonesia. Salah satu jenis penyakit yang cukup membahayakan udang adalah vibriosis yang disebabkan oleh bakteri Vibrio Masuknya bakteri Vibrio dalam usaha budi daya udang di tambak dapat berasal dari air laut dan benur yang digunakan. Boer et al. (1993) melaporkan bahwa induk yang berasal dari laut positif membawa bakteri bercahaya sehingga dapat menular pada benur (larva) dan bakteri tersebuut akhirnya terbawa masuk ke tambak

Bakteri Vibrio merupakan bakteri gram negatif yang berbentuk batang (rods), bersifat anaerobik fakultatif, katalase dan oksidase positif, dapat memfermentasi gula dan menguraikan nitrat (Lewis, 1973; Austin \& Austin, 1993; Alsina \& Blanch, 1994; Baumann et al., 1994).

\footnotetext{
Peneliti pada Balai Penelitian Perikanan Pantai
} 
Jenis bakteri Vibrio yang ditemukan menyerang udang antara lain V. harveyi (Lightner, 1988 \& 1992 Boer et al., 1993; Jiravanichpaisal et al., 1994 Atmomarsono et al., 1995). Bakteri ini menyerang baik. larva udang di panti-panti perbenihan maupun udang yang dibudidayakan di tambak. Penyakit yang ditimbulkan oleh bakteri ini dikenal dengan nama penyakit kunang-kunang atau penyakit udang menyala. Pada kondisi gelap, larva udang yang terserang $V$. harveyi akan bercahaya dalam tangki pemeliharaannya, sedangkan udang yang dipelihara di tambak tampak bercahaya jika air tambak diterpa angin. Selain $V$. harveyi, juga diidentifikasi jenis Vibrio lain yang menyerang udang di tambak, antara lain $V$. parahaemolyticus, $V$. alginolyticus, dan $V$. anguillarum (Anderson et al., 1988; Lightner et al., 1992; Nash et al., 1992; Partasasmita, 1993; Chen \& Hanna, 1994 Abraham \& Manley, 1995; Chanratchakool et al. 1995). Udang yang terserang Vibrio biasanya menunjukkan gerakan yang lemah dan menyentaknyentak, kulit karapas rusak dan berwarna coklat atau hitam, dan kadang-kadang berwarna merah di bagian ekor atau kaki renangnya (Rukyani, 1993).

Sedimen tambak merupakan salah satu media pertumbuhan bakteri, baik yang bermanfaat maupun yang merugikan. Pemberian pakan yang tidak. terkontrol selama proses budi daya mengakibatkan akumulasi limbah organik di dasar tambak, sehingga menyebabkan terbentuknya lapisan anaerob yang menghasilkan $\mathrm{H}_{2} \mathrm{~S}$ dan bahan toksik lainnya (Anderson et al., 1988). Akibatnya bakteri patogen (Aeromonas spp. dan Vibrio spp.), jamur, parasit dan virus mudah berkembang dan memungkinkan timbulnya penyakit pada udang (Austin, 1987; Lightner et al., 1992; Nash et al., 1992; Atmomarsono et al. 1993; Madeali et al., 1993; Muliani \&. Mangampa, 1993; Tompo et al., 1993). Hasil isolasi dan identifikasi bakteri Vibrio spp. pada sedimen tambak mineral dan tambak tanah gambut ditemukan beberapa bakteri Vibrio, antara lain Vibrio sp., $V$. alginolyticus, $V$. anguillarum, $V$. cholerae, $V$. costicola, $V$. harveyi, $V$. mimicus, $V$. nereis, dan $V$. tubiashii (Muliani \& Hanafi 1997; Muliani et al., 1997). Keberadaan bakteri Vibrio spp. di dalam lingkungan tambak tidak akan menimbulkan penyakit, jika kualitas tanah dan air tambak dapat dipertahankan dan udang tidak dalam keadaan stres.

Tingkat patogenisitas beberapa jenis bakteri Vibrio yang diisolasi dari air laut, udang dan air pemeliharaan larva udang telah banyak dilakukan (Lavilla-Pittago et al., 1990; Karunasagar et al., 1994; Prayitno \& Latchford, 1995). Penelitian ini ditujukan untuk mengetahui tingkat patogenisitas beberapa jenis bakteri Vibrio spp. yang diisolasi dari sedimen tambak terhadap udang windu.

\section{BAHAN DAN METODE}

Penelitian dilakukan di Laboratorium Basah Balai Penelitian Perikanan Pantai, dengan tahapan kerja sebagai berikut:Isolasi dan identifikasi bakteri Vibrio spp. dari sedimen tambak

Sedimen tambak diambil dengan menggunakan bor tanah berdiameter $10 \mathrm{~cm}$ yang di dalamnya dilengkapi dengan cincin-cincin pembatas. Sedimen dibawa ke Laboratorium Patologi Balai Penelitian Perikanan Pantai menggunakan botol sampel steril. Isolasi bakteri Vibrio dilakukan dengan cara mengambil $1 \mathrm{~g}$ sedimen yang kemudian diencerkan dengan menggunakan larutan air laut buatan (Muir \& Owens, 1996). Setelah itu diinokulasikan satu $\mathrm{mL}$ ke dalam media TCBS (Thiosulfate Citrate Bile Sucrose) broth dalam multiwell plate 24 lubang (Muir \& Owens 1996) dan kemudian diinkubasi pada suhu $28^{\circ} \mathrm{C}$ selama 48 jam. Pemisahan koloni bakteri Vibrio dilakukan menggunakan TCBS agar dalam cawan petri, sedangkan uji karakterisasi untuk identifikasi spesies dilakukan berdasarkan metode yang dikemukakan oleh Austin (1991); Austin \& Austin (1993); Alsina \& Blanch (1994); Baumann et al., 1994; Brock et al. (1994); Muir (1996a). Untuk menentukan spesies dari bakteri Vibrio, data hasil uji biokimia yang diperoleh diolah dengan menggunakan perangkat lunak Fortran Computer Progam (Muir, 1996b). Isolat bakteri Vibrio spp. yang diperoleh diremajakan secara berkala untuk selanjutnya diuji patogenisitasnya.

\section{Perbanyakan bakteri Vibrio spp.}

Sebelum dilakukan perbanyakan bakteri dalam nutrient broth untuk infeksi buatan ke dalam media pemeliharaan udang, dilakukan uji pendahuluan untuk pendugaan kepadatan bakteri dengan cara sebagai berikut yaitu isolat bakteri dari sedimen tambak ditumbuhkan pada media TCBS agar dalam cawan petri selama 48 jam pada suhu $28^{\circ} \mathrm{C}$, kemudian diambil sebanyak 15 jarum ose dan ditumbuhkan pada nutrient broth volume $100 \mathrm{~mL}$ selama 48 jam pada suhu $28^{\circ} \mathrm{C}$ dengan tiga ulangan. Penghitungan populasi bakteri dalam nutrient broth dilakukan dengan cara pengenceran bertingkat $\left(10^{-1}, 10^{-2}, 10^{-3}, 10^{-4}\right.$, dan seterusnya), yaitu tiap $1 \mathrm{~mL}$ larutan bakteri diencerkan ke dalam $9 \mathrm{~mL}$ larutan garam fisiologis (Benson, 1985). Kemudian dari masing-masing pengenceran diambil $0,1 \mathrm{~mL}$ dan ditumbuhkan pada media TCBS agar dalam cawan petri selama 48 jam pada suhu $28^{\circ} \mathrm{C}$. Setelah diketahui populasi bakteri dalam nutrient broth, maka volume suspensi bakteri dalam nutrient broth yang akan diinfeksikan ke dalam media pemeliharaan udang windu dapat dihitung dengan menggunakan rumus pengenceran sebagai berikut: 


$$
\mathrm{N} 1 \mathrm{~V} 1=\mathrm{N} 2 \mathrm{~V} 2
$$

dengan

N1 = Kepadatan populasi bakteri Vibrio dalam nutrient broth

V1 = Volume suspensi bakteri Vibrio dalam nutrient broth yang dibutuhkan

$\mathrm{N} 2$ = Kepadatan populasi bakteri yang dikehendaki

V2 = Volume media air dalam wadah pemeliharaan udang windu

\section{Infeksi buatan bakteri Vibrio ke dalam wadah pemeliharaan udang windu}

Stoples yang berkapasitas $3 \mathrm{~L}$ sebanyak 39 buah digunakan sebagai wadah penelitian. Setiap stoples diisi air laut bersalinitas 25 ppt sebanyak $2 \mathrm{~L}$ yang telah disterilkan dengan kaporit $150 \mathrm{mg} / \mathrm{L}$ dan dinetralisir dengan Natrium Tiosulfat $75 \mathrm{mg} / \mathrm{L}$. Pada setiap stoples ditebarkan 10 ekor udang windu PL 45 sebagai hewan uji. Infeksi bakteri terhadap benur windu dilakukan dengan cara perendaman (Hameed, 1995). Bakteri V. alginolyticus, V. costicola, V. harveyi, dan $V$. mimicus yang diisolasi dari sedimen tambak diuji patogenisitasnya terhadap udang windu dengan kepadatan $10^{2}, 10^{4}$, dan $10^{6} \mathrm{cfu} / \mathrm{mL}$, masingmasing dengan tiga ulangan.

\section{Pengamatan perkembangan populasi bakteri dan mortalitas udang windu, P. monodon}

Perkembangan populasi bakteri Vibrio dalam air media pemeliharaan udang pada setiap perlakuan diamati setiap 24 jam hingga 96 jam perendaman. Sedangkan mortalitas udang windu diamati sejak diinfeksi dengan bakteri Vibrio hingga 96 jam perendaman. Data mortalitas udang yang diperoleh dianalisis ragam dan dilanjutkan dengan uji Beda Nyata Terkecil (BNT) dengan bantuan perangkat lunak "Statistik versi 3"

\section{HASIL DAN BAHASAN}

\section{Identifikasi Bakteri Vibrio pada Sedimen Tambak}

Keempat jenis bakteri Vibrio spp. yang digunakan dalam penelitian ini merupakan bakteri yang diisolasi dari sedimen tambak udang. Hasil identifikasi secara biokimiawi menunjukkan bahwa keempat jenis bakteri tersebut adalah $V$. alginolyticus, V. costicola, $V$. harveyi, dan V. mimicus. Hasil uji biokimiawi dari masing-masing jenis bakteri Vibrio tersebut disajikan pada Tabel 1. Dari Tabel tersebut terlihat bahwa masing-masing jenis bakteri mempunyai sifat biokimiawi yang berbeda satu sama lain. Beberapa strain (galur) dari $V$. harveyi mampu mereduksi lisin dan ornitin, tetapi tidak terhadap arginin, menghasilkan asam dari kellobiosa, glukosa, sukrosa dan dapat mereduksi nitrat dengan Voges-Proskauer (VP) negatif (Austin \& Austin, 1993). Selanjutnya dikatakan bahwa di antara strain dari $V$. alginolyticus ada yang mampu menghasilkan $\mathrm{H}_{2} \mathrm{~S}$, indol, ornitin dekarboksilase, dan Voges-Proskauer positif. Alsina \& Blanch (1994) melaporkan bahwa beberapa strain V. costicola mampu memproduksi arginin, VogesProskauer positif dan mampu mereduksi nitrat, sedangkan strain $V$. mimicus beberapa di antaranya memproduksi lisin dan dapat tumbuh pada suhu $40^{\circ} \mathrm{C}$ dengan indol positif tetapi Voges-Proskauer negatif, dan dapat mereduksi nitrat.

\section{Uji perbanyakan bakteri Vibrio}

Hasil uji pendahuluan terhadap perbanyakan bakteri $V$. alginolyticus, $V$. costicola, $V$. harveyi, dan $V$. mimicus menggunakan media nutrient broth 100 $\mathrm{mL}$ yang diinkubasi selama 48 jam pada suhu $28^{\circ} \mathrm{C}$ masing-masing mencapai kepadatan 109, 109, 108, dan $109 \mathrm{cfu} / \mathrm{mL}$. Hal ini menunjukkan bahwa pada kondisi yang sama perkembangan populasi bakteri $V$. harveyi lebih lambat dibanding ketiga bakteri Vibrio lainnya.

\section{Perkembangan populasi bakteri Vibrio dalam wadah pemeliharaan udang windu}

Perkembangan bakteri $V$. harveyi dalam wadah pemeliharaan udang windu disajikan pada Gambar 1. Pada gambar tersebut terlihat bahwa pada 24 jam pertama dengan konsentrasi inokulum $10^{2} \mathrm{cfu} / \mathrm{mL}$. $V$. harveyi memperlihatkan perkembangan populasi yang lebih lambat $\left(5,5 \times 10^{5} \mathrm{cfu} / \mathrm{mL}\right)$ dibanding dengan ketiga jenis vibrio lainnya yaitu $V$. alginolyticus $\left(1,0 \times 10^{6} \mathrm{cfu} / \mathrm{mL}\right), V$. costicola $\left(1,2 \times 10^{6} \mathrm{cfu} / \mathrm{mL}\right)$, dan $V$. mimicus $\left(1,0 \times 10^{6} \mathrm{cfu} / \mathrm{mL}\right)$. Dari gambar tersebut telihat pula bahwa populasi bakteri meningkat pada hari pertama, tetapi cenderung menurun setelah hari ke dua dan ke tiga dan meningkat lagi pada hari ke empat. Hal ini sesuai dengan pendapat Atmomarsono et al. (1995) yang mengatakan bahwa pergantian air tambak yang menggunakan air tandon dianjurkan setelah air ditandon selama tiga hari. $\mathrm{Hal}$ ini disebabkan populasi bakteri akan menurun setelah tiga hari ditampung dalam petak tandon

\section{Mortalitas udang windu}

Hasil pengamatan terhadap mortalitas udang windu yang diinfeksi dengan beberapa jenis bakteri Vibrio dapat dilihat pada Tabel 2. Pada Tabel tersebut terlihat bahwa pada perendaman 24 jam dengan kepadatan $10^{2}$ dan $10^{4} \mathrm{cfu} / \mathrm{mL}$, keempat jenis bakteri belum menyebabkan kematian yang berbeda 
Tabel 1. Hasil uji biokimiawi bakteri Vibrio yang digunakan sebagai bioindikator

Table 1. Biochemical test of vibrios used as bioindicator

\begin{tabular}{|c|c|c|c|c|}
\hline \multirow{2}{*}{$\begin{array}{c}\text { Tes Biokimiawi } \\
\text { (Biochemical test) }\end{array}$} & \multicolumn{4}{|c|}{ Jenis Bakteri (Kind of Bacteria) } \\
\hline & V. alginolyticus & V. costicola & V. Harveyi & V. mimicus \\
\hline Swarming & - & \pm & + & - \\
\hline Luminescence & - & - & - & - \\
\hline VP test & + & - & - & - \\
\hline Arginine dihydrolase & - & + & - & - \\
\hline Gas from glucose & - & - & - & - \\
\hline Growth at $40^{\circ} \mathrm{C}$ & + & - & + & + \\
\hline Lysine decarboxylase & + & - & + & + \\
\hline Pigmentation & \pm & \pm & \pm & \pm \\
\hline Amylase & + & - & + & + \\
\hline Sucrose & + & + & + & - \\
\hline Indole & - & - & - & - \\
\hline Ornithine decarboxylase & + & - & + & + \\
\hline Putriscine & - & - & - & - \\
\hline Ethanol & - & - & - & - \\
\hline Serine & + & - & - & - \\
\hline Heptanoate & + & - & + & + \\
\hline Xanthine & - & - & - & - \\
\hline Aminobutyrate & - & - & - & - \\
\hline L-Arabinose & - & - & - & - \\
\hline D-Cellobiose & + & - & + & + \\
\hline Glucuronate & \pm & \pm & \pm & \pm \\
\hline Alfa-ketoglutarate & - & - & - & - \\
\hline L-alanine & + & + & + & + \\
\hline Leucine & + & + & - & + \\
\hline Propionate & + & + & + & + \\
\hline
\end{tabular}

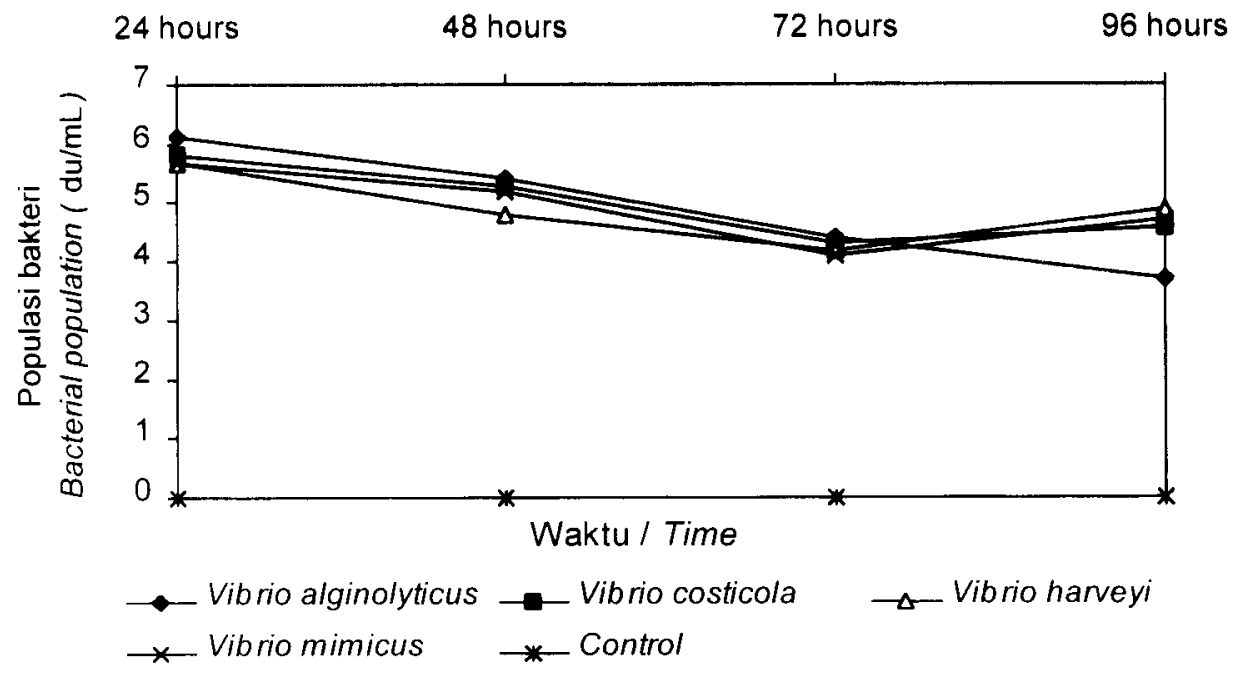

Gambar 1. Perkembangan populasi bakteri dalam wadah pemeliharaan udang windu $P$. monodon selama 96 jam

Figure 1. The growth of bacteria population of tiger shrimp $P$. monodon in cultured medium during 96 hours 
$(P>0,05)$ dengan kontrol. Tetapi pada kepadatan $10^{6}$ $\mathrm{cfu} / \mathrm{mL} V$. harveyi telah menyebabkan kematian lebih banyak $(P<0,05)$ dibanding perlakuan yang lainnya. Hal ini menunjukkan bahwa $V$. harveyi yang digunakan dalam penelitian ini lebih bersifat patogen dibanding dengan $V$. alginolyticus, $V$. costicola, dan $V$. mimicus. Uji patogenisitas bakteri $V$. harveyi terhadap udang windu dengan metode penyuntikan yang dilakukan oleh Jiravanichpaisal et al. (1994) menyebabkan kematian udang $80 \%$ setelah 24 jam.

Pada masa perendaman 48 jam dengan kepadatan $10^{2}$ dan $10^{4}, \mathrm{~V}$. alginolyticus, V. costicola, dan $V$. mimicus belum menyebabkan kematian yang berbeda $(P>0,05)$, tetapi ketiganya nyata kurang patogen $(P<0,05)$ bila dibandingkan dengan $V$. harveyi pada kepadatan $10^{6} \mathrm{cfu} / \mathrm{mL}$ yang telah mematikan $53,3 \%$ udang uji. Tingkat kematian udang tersebut masih relatif lebih rendah dibandingkan yang dilaporkan oleh Lavilla-Pitogo (1990) dan Prayitno \& Latchford (1995) masing-masing sebesar 69,0\% dan $51,5 \%$ dengan kepadatan bakteri $10^{3} \mathrm{cfu} / \mathrm{mL}$ dan masa perendaman $48 \mathrm{jam}$. Hal ini menunjukkan bahwa dengan kepadatan $10^{3} \mathrm{cfu} / \mathrm{mL}$ Vibrio harveyi sudah patogen terhadap udang windu, sementara ketiga jenis Vibrio lainnya belum tergolong patogen

Seperti halnya pada masa perendaman 24 dan 48 jam, pada perendaman 72 jam $V$. alginolyticus, V. costicola, dan V. mimicus belum menyebabkan kematian yang berbeda nyata $(P<0,05)$ untuk semua tingkat kepadatan. Pada kepadatan $10^{4} \mathrm{cfu} / \mathrm{mL}, V$. harveyi menyebabkan kematian yang lebih banyak $(P<0,05)$ dibandingkan dengan $V$. alginolyticus $\left(10^{2}\right.$ $\mathrm{cfu} / \mathrm{mL}), V$. costicola $\left(10^{2}\right.$ dan $\left.10^{4} \mathrm{cfu} / \mathrm{mL}\right), V$. harveyi $\left(10^{2} \mathrm{cfu} / \mathrm{mL}\right)$, serta kontrol. Sedangkan kematian udang windu pada kepadatan $V$. harveyi $10^{6} \mathrm{cfu} / \mathrm{mL}$ berbeda nyata $(P<0,05)$ dengan perlakuan lainnya, dengan kematian udang telah mencapai $93,3 \%$.

Pada perendaman 96 jam, $V$. alginolyticus dengan kepadatan $10^{6} \mathrm{cfu} / \mathrm{mL}$, menyebabkan kematian sebesar $50 \%$, sedangkan $V$. harveyi pada kepadatan $10^{4}$ dan $10^{6} \mathrm{cfu} / \mathrm{mL}$ telah menyebabkan kematian masing-masing sebesar $66,7 \%$ dan $100 \%$. Karunasagar et al. (1994) mengemukakan bahwa pada kepadatan $10^{6} \mathrm{cfu} / \mathrm{mL}, V$. harveyi yang diisolasi dari air laut dan tangki pemeliharaan larva udang windu menyebabkan kematian terhadap post larva udang windu masing-masing sebesar $90 \%$ dan $100 \%$ setelah hari ke lima

Secara statistik kematian udang uji oleh $V$. alginolyticus dengan kepadatan $10^{6} \mathrm{cfu} / \mathrm{mL}$ dan $V$. harveyi dengan kepadatan $10^{4} \mathrm{cfu} / \mathrm{mL}$ adalah tidak berbeda nyata $(P>0,05)$, sedangkan pada kepadatan yang sama, $V$. harveyi nyata lebih patogen $(P<0,05)$ dari pada $V$. alginolyticus, $V$. costicola, dan $V$. mimicus. Dua jenis Vibrio terakhir bahkan dapat dikatakan tidak patogen terhadap udang windu PL45

Tabel 2. Rata-rata tingkat kematian udang windu $P$. monodon selama 96 jam perendaman Table 2. Average mortality rate (\%) of tiger shrimp P. monodon during 96 hour incubation

\begin{tabular}{|c|c|c|c|c|c|}
\hline \multirow{2}{*}{$\begin{array}{l}\text { Perlakuan } \\
\text { Treatments }\end{array}$} & \multirow{2}{*}{$\begin{array}{l}\text { Awal penebaran (ekor) } \\
\text { Stocking density (pcs) }\end{array}$} & \multicolumn{4}{|c|}{ Lama Perendaman (incubation time) } \\
\hline & & $\begin{array}{l}24 \text { jam } \\
24 \text { hours }\end{array}$ & $\begin{array}{l}48 \text { jam } \\
48 \text { hours }\end{array}$ & $\begin{array}{l}72 \text { jam } \\
72 \text { hours }\end{array}$ & $\begin{array}{l}96 \text { jam } \\
96 \text { hours }\end{array}$ \\
\hline $\begin{array}{l}\text { V. alginolyticus } \\
10^{2} \mathrm{cfu} / \mathrm{mL} \\
10^{4} \mathrm{cfu} / \mathrm{mL} \\
10^{6} \mathrm{cfu} / \mathrm{mL}\end{array}$ & $\begin{array}{l}30 \\
30 \\
30\end{array}$ & $\begin{array}{l}0\left(0.0^{c}\right) \\
0\left(0.0^{c}\right) \\
2\left(6.7^{b}\right)\end{array}$ & $\begin{array}{c}2\left(6.7^{b c}\right) 1 \\
\left(3.3^{c}\right) \\
5\left(16.7^{b c}\right)\end{array}$ & $\begin{array}{c}2\left(6.7^{c}\right) \\
4\left(13.3^{b c}\right) \\
9\left(30.0^{b}\right)\end{array}$ & $\begin{array}{c}3\left(10.0^{d}\right) \\
7\left(23.3^{c d}\right) \\
15\left(50.0^{b c}\right)\end{array}$ \\
\hline $\begin{array}{l}\text { V. Costicola } \\
10^{2} \mathrm{cfu} / \mathrm{mL} \\
10^{4} \mathrm{cfu} / \mathrm{mL} \\
10^{6} \mathrm{cfu} / \mathrm{mL}\end{array}$ & $\begin{array}{l}30 \\
30 \\
30\end{array}$ & $\begin{array}{l}2\left(6.7^{b}\right) \\
0\left(0.0^{c}\right) \\
0\left(0.0^{c}\right)\end{array}$ & $\begin{array}{l}4\left(13.3^{b}\right) \\
0\left(0.0^{c}\right) \\
2\left(6.7^{c}\right)\end{array}$ & $\begin{array}{c}4\left(13.3^{b c}\right) \\
2\left(6.7^{c}\right) \\
5\left(16.7^{c}\right)\end{array}$ & $\begin{array}{l}5\left(16.7^{c d}\right) \\
5\left(16.7^{c d}\right) \\
5\left(16.7^{c d}\right)\end{array}$ \\
\hline $\begin{array}{l}\text { V. harveyl } \\
10^{2} \mathrm{cfu} / \mathrm{mL} \\
10^{4} \mathrm{cfu} / \mathrm{mL} \\
10^{6} \mathrm{cfu} / \mathrm{mL}\end{array}$ & $\begin{array}{l}30 \\
30 \\
30\end{array}$ & $\begin{array}{l}1\left(3.3^{b c}\right) \\
2\left(6.7^{b}\right) \\
0\left(0.0^{a}\right)\end{array}$ & $\begin{array}{c}2\left(6.7^{b c}\right) \\
5\left(20.0^{b}\right) \\
16\left(53.3^{a}\right)\end{array}$ & $\begin{array}{c}3\left(10.0^{b c}\right) \\
9\left(30.0^{b}\right) \\
28\left(93.3^{a}\right)\end{array}$ & $\begin{array}{c}4\left(13.3^{d}\right) \\
20\left(66.7^{c d}\right) \\
30\left(100^{a}\right)\end{array}$ \\
\hline $\begin{array}{l}\text { V. mimicus } \\
10^{2} \mathrm{cfu} / \mathrm{mL} \\
10^{4} \mathrm{cfu} / \mathrm{mL} \\
10^{6} \mathrm{cfu} / \mathrm{mL}\end{array}$ & $\begin{array}{l}30 \\
30 \\
30 \\
\end{array}$ & $\begin{array}{l}0\left(0.0^{C}\right) \\
0\left(0.0^{C}\right) \\
0\left(0.0^{c}\right)\end{array}$ & $\begin{array}{c}0\left(0^{c}\right) \\
0\left(0^{c}\right) \\
1\left(3.3^{c}\right) \\
\end{array}$ & $\begin{array}{c}1\left(3.3^{c}\right) \\
1\left(3.3^{c}\right) \\
3\left(10.0^{b c}\right) \\
\end{array}$ & $\begin{array}{c}2\left(6.7^{d}\right) \\
4\left(13.3^{\text {cd }}\right) \\
7\left(23.3^{\text {cd }}\right) \\
\end{array}$ \\
\hline Kontrol (Control) & 30 & $0\left(0.0^{c}\right)$ & $0\left(0^{c}\right)$ & $2\left(6.7^{c}\right)$ & $3\left(10.0^{c}\right)$ \\
\hline
\end{tabular}


dalam perendaman selama 96 jam, dengan kematian yang ditimbulkannya tidak berbeda nyata $(P>0,05)$ dengan kontrol (Tabel 2).

\section{KESIMPULAN}

1. Dengan kepadatan bakteri dan masa perendaman yang sama didapatkan bahwa $V$. harveyi tergolong lebih patogen daripada $V$. alginolyticus, V. costicola, dan V. mimicus.

2. Tingkat kematian udang windu yang diinfeksi dengan $V$. harveyi $10^{6} \mathrm{cfu} / \mathrm{mL}$ pada masa perendaman 24 jam lebih tinggi $(P<0,05)$ daripada perlakuan yang lainnya.

3. $V$. alginolyticus patogen terhadap udang windu pada kepadatan $10^{6} \mathrm{cfu} / \mathrm{mL}$ dengan masa perendaman $48 \mathrm{jam}$ atau $10^{4} \mathrm{cfu} / \mathrm{mL}$ dengan masa perendaman 96 jam.

4. V. costicola dan V. mimicus yang berasal dari sedimen tambak tergolong bakteri yang tidak patogen terhadap udang windu

\section{UCAPAN TERIMA KASIH}

Diucapkan terima kasih kepada Sdri. Nurjanna dan Nurbaya atas bantuan mereka dalam pelaksanaan penelitian di Laboratorium Patologi Balai Penelitian Perikanan Pantai, Maros.

\section{DAFTAR PUSTAKA}

Abraham, T.J., and R. Manley. 1995. Luminous and nonluminous Vibrio harveyi associated with shell diseases in cultured Penaeus indicus J. Aqua. Trop. (10): 273-276

Alsina, M. and A.R. Blanch. 1994. A set of keys for biochemical identification of environmental Vibrio species. J. Applied Bacteriology (76):79-85.

Anderson, I.G., M.N. Shamsuddin, M. Shariff, and G. Nash. 1988. Bacterial septicemia in juvenile tiger shrimp, Penaeus monodon, cultured in Malaysian brackishwater ponds. Asian Fisheries Science 2:93108

Atmomarsono, M., Muliani, dan S. Ismawati. 1995. Prospek penggunaan tandon pada budi daya udang windu. Makalah disajikan pada Ekspose Hasil Penelitian di Instalasi Pengkajian Teknologi Pertanian Wonocolo, Surabaya Tanggal 3-4 Juli 1995. 10 pp.

Atmomarsono, M., M.I. Madeali, Muliani, dan A. Tompo. 1993. Kasus penyakit udang windu di Kabupaten Pinrang. Dalam Hanafi, A., M. Atmomarsono, dan S. Ismawati (Eds). Prosiding Seminar Hasil Penelitian Perikanan Budi Daya Pantai, Maros 16-19 Juli 1993. p. $35-40$

Austin, B. 1987. Marine Microbiology. Cambridge Univeristy Press. Cambridge. 222 pp.
Austin, B. 1991. Methods in Aquatic Bacteriology. John Wiley and Sons. Chichester. New York. Brisbane. Toronto. Singapore. 425 pp.

Austin, B. and D. A. Austin. 1993. Bacterial Fish Pathogens. Disease in Farmed and Wild Fish. Second edition. New York. London. Toronto. Sydney. Tokyo. Singapore. $384 \mathrm{pp}$

Baumann, P., A. L. Furniss, and J. V. Lee. 1994. Facultative anaerobic gram negative rods. In J. G. Holt, N. R. Krieg, P. H. A. Sneath, J. T. Staley, and S. T. Wilkins (Eds.), Bergey's Manual of Determinative Bacterio/ogy. Ninth Edition. The William and Wilkins, Baltimore, Maryland, USA. p.175-289

Benson, H. J. 1985. Microbiological Applications: A Laboratory Manual in General Microbiology. Fourth Edition. Wm. C. Brown Publishers. Dubuque, lowa. 450 $\mathrm{pp}$.

Boer, D. R., Zafran, and T. Ahmad. 1993. Penanggulangan penyakit udang windu (Penaeus monodon) di panti benih. Dalam Hanafi, A., M. Atmomarsono, dan S. Ismawati (Eds.), Prosiding Seminar Hasil Penelitian Perikanan Budidaya Pantai, Maros. 16-19 Juli 1993. p.9-12.

Brock, T. D., M. T. Madigan, J.M. Martinko, and J. Parker 1994. Biology of Microorganism. Seventh Edition Prentice Hall International, Inc. 909pp.

Chanratchakool, P., J. F. Turnbull, S. F. Smith, and C Limsuwan. 1995. Health Management in Shrimp Ponds. $2^{\text {nd }}$ Edition. Aquatic Animal Health Research Institute. Department of Fisheries. Kasetsart University Campus. Bangkok. 111 pp.

Chen, D. and P. J. Hanna. 1994. Immunodetection of specific Vibrio bacteria attaching to tissue of the giant tiger prawn Penaeus monodon. Dis. Aqua. Org., 20:159-162

Hameed, A.S.S. 1995. Susceptibility of three Penaeus $\mathrm{sp}$. to a Vibrio campbelli-like bacterium. J. World Aqua Soc., 26 (3):315-319.

Jiravanichpaisal, P. T., T. Miyasaki, and C. Limsuwan 1994. Histopathology, biochemistry, and pathogenecity of Vibrio harveyi infecting black tiger prawn Penaeus monodon. J. Aqua. Animal Health, 6:27-33

Karunasagar, I., R. Pai, G.R. Malathi, and I. Karunasagar 1994. Mass mortality of Penaeus monodon larvae due to antibiotic-resistant Vibrio harveyi infection. Aquaculture (128):203-209

Lavilla-Pitogo, C.R., C. L. Baticados, E.R. Cruz-Lacierda and L. D. de la Pena. 1990. Occurrence of luminous bacterial disease of Penaeus monodon larvae in the Philippines. Aquaculture (91):1-13.

Lewis, D. 1973. Predominant aerobic bacteria of fish and shellfish. Texas A \& M University, Sea Grant Publ. No. 401.102pp.

Lightner, D.V. 1988. Vibrio disease of penaeid shrimp. In Sindermann, C.J. and D.V. Lightner (Eds.), Disease Diagnosis And Control In North American Marine Aquaculture. $2^{\text {nd }}$ Edition. Elsevier. Amsterdam-OxfordNew York-Tokyo. p.42-47 
Lightner, D.V., T.A. Bell, R.M. Redman, L.L. Mohley, J.M Natividad, A. Rukyani, and A. Poernomo. 1992. A review of some major diseases of economic significant on penaeid prawns/shrimps of the Americans and Indopacific. In Shariff, I. N., R.P. Subasinghe, and R.J. Arthur (Eds.), Diseases in Asian Aquaculture. Fish Health Section, Asian Fisheries Society, Manila. Philippines. p.57-80.

Madeali, M.I., M. Atmomarsono, A. Tompo, dan Muliani. 1993. Studi kasus penyebab kematian udang windu, Penaeus monodon di tambak intensif. J. Penelitian Budidaya Pantai, 9 (4):23-28.

Muir, P. 1996a. Media Used in Vibrio and Photobacterium Identification. Department of Microbiology, Biomedical and Tropical Veterinary Sciences. James Cook University of North Queensland. Australia. $7 \mathrm{pp}$.

Muir, P. 1996b. Identification of Vibrio and Pseudomonas Bacteria. Department of Microbiology, Biomedical and Tropical Veterinary Sciences. James Cook University of North Queensland. Australia. $6 \mathrm{pp}$.

Muir, P. and L. Owens. 1996. Sampling for Sulphur-Cycle Bacteria of Sediment. Department of Microbiology, Biomedical and Tropical Veterinary Sciences. James Cook University of North Queensland. Australia. $7 \mathrm{pp}$.

Muliani dan M. Mangampa. 1993. Identifikasi parasit pada budi daya udang. Penaeus monodon. Dalam Hanafi, A., M. Atmomarsono, dan S. Ismawati (Eds.). Prosiding Seminar Hasil Penelitian Perikanan Budidaya Pantai, Maros 16-19 Juli 1993. p.31-34.

Muliani, M. Atmomarsono, M.I. Madeali, T. Ahmad, dan A. Hanafi. 1997. Kelimpahan dan komposisi jenis bakteri Vibrio pada sedimen tambak. Laporan Hasil Penelitian. Balai Penelitian Perikanan Pantai. 10 pp.

Muliani dan A. Hanafi. 1997. Identifikasi dan karakterisasi organisme pada tambak tanah gambut. Prosiding II. Seminar Nasional Biologi XV. Perhimpunan Biologi Indonesia Cabang Lampung dan Universitas Lampung. Bandar Lampung. p.470-475.

Nash, G., C. Nithimathachoke, C. Tungmandi, A. Arkarjamorn, P. Prathampipat, and $P$ Ruamthaveesud. 1992. Vibriosis and its control in pond-reared Penaeus monodon in Thailand. In Shariff, I. N., R.P. Subasinghe, and R.J. Arthur (Eds.), Diseases in Asian Aquaculture. Fish Health Section, Asian Fisheries Society, Manila. Philippines. p.143150.

Partasasmita, S. 1993. Hama dan penyakit udang. Warta Balitdita 5(1):31-32.

Prayitno, S.B. dan J.W. Latchford. 1995. Experimental infections of crustaceans with luminous bacteria related to Photobacterium and Vibrio. Effect of salinity and $\mathrm{pH}$ on infectiousity. Aquaculture, (135): 105-112.

Rukyani, A. 1993. Penanggulangan penyakit udang windu, Penaeus monodon. Dalam Hanafi, A., M. Atmomarsono, dan S. Ismawati (Eds.). Prosiding Seminar Hasil Penelitian Perikanan Budidaya Pantai, Maros 16-19 Juli 1993. p.1-8.

Tompo, A., M. Atmomarsono, M.I. Madeali, dan Muliani, 1993. Prevalensi dan intensitas ektoparasit pada udang windu, Penaeus monodon di tambak Sulawesi Selatan. J. Penel. Budidaya Pantai. 9 (3):111-118. 